\title{
PENGGUNAAN MEDIA KARTU HURUF UNTUK MENINGKATKAN KEMAMPUAN MENULIS PERMULAAN DITKINTAN KOMARA KELOMPOK B
}

\begin{abstract}
Sri Astuti ${ }^{1}$
ABSTRAK

Penelitian ini dilatarbelakangi oleh adanya fakta di lapangan yang menunjukkan bahwa kemampuan menulis permulaan siswa Taman Kanak-kanak masih kurang. Anak masih banyak melakukan kesalahan (penulisan huruf dalam kata atau masih ada kekurangan). Hal ini terjadi karena guru kurang maksimal dalam menggunakan metode atau media pembelajaran. Maka peneliti mencoba menerapkan penggunaan media kartu huruf untuk meningkatkan kemampuan menulis permulaan. Rumusan masalah dalam penelitian ini adalah bagaimana aktifitas belajar anak dalam kegiatan menulis permulaan dengan menggunakan media kartu huruf di TK Intan Komara? dan bagaimana meningkatkan hasil belajar anak dalam kegiatan menulis permulaan dengan menggunakan media kartu huruf di TK Intan Komara? Tujuan dari penelitian yang dilaksanakan adalah untuk mengetahui gambaran tentang penerapan media kartu huruf dalam meningkatkan kemampuan menulis permulaan di Taman Kanak-kanak. Jenis penelitian yang digunakan adalah penelitian tindakan kelas (PTK) dengan model Elliot. Subjek dalam penelitian ini adalah Anak-anak TK Intan Komara Kelompok B tahun ajaran 2014/2015, yang berjumlah 15 orang siswa dengan 6 orang anak laki-laki dan 9 anak perempuan. Berdasarkan hasil penelitian yang diperoleh menunjukkan bahwa kemampuan menulis permulaan Anak Tk Intan Komara Kelompok B mengalami peningkatan. Hal ini dibuktikan dengan hasil pencapaian perkembangan siswa yang mengalami peningkatan pada setiap siklusnya, yaitu (1) pada siklus I, Pencapaian perkembangan siswa sebesar $79 \%$. Pada siklus II, pencapaian perkembangan siswa sebesar $82 \%$. Pada siklus III, pencapaian perkembangan siswa adalah 90\%. Dengan demikian, dapat disimpulkan bahwa penggunaan media kartu huruf dapat meningkatkan kemampuan menulis permulaan Anak Tk Intan Komara Kelompok B mengalami peningkatan.
\end{abstract}

Kata kunci: Media Kartu huruf, Menulis Permulaan TK

${ }^{1}$ Mahasiswa Prodi PGPAUD Kampus UPI Cibiru 


\section{A. PENDAHULUAN}

Anak usia dini adalah individu yang berbeda, unik dan memiliki karakteristik sendiri sesuai dengan tahapan usianya. Menurut Undang-undang Nomor 20 Tahun 2003 tentang Sistem Pendidikan Nasional mengamanatkan dengan tegas perlunya penanganan pendidikan anak usia dini, hal tersebut bisa dilihat pada pasal 1 butir 14 yang menyatakan bahwa:"Pendidikan anak usia dini adalah suatu upaya pembinaan yang ditunjukkan kepada anak sejak lahir sampai dengan usia enam tahun yang dilakukan melalui pemberian rangsangan pendidikan untuk membantu pertumbuhan dan perkembangan jasmani dan rohani agar anak memiliki kesiapan dalam memasuki pendidikan lebih lanjut. (Kemendiknas, 2013, hlm.1)

Terdapat beberapa definisi mengenai anak usia dini. Definisi yang pertama, anak usia dini adalah anak yang berusia nol tahun atau sejak lahir sampai berusia kurang lebih delapan tahun (0-8). Sedangkan definisi yang kedua, menurut Undang-Undang RI No. 20 Tahun 2003 Tentang Sistem Pendidikan Nasional Pasal 1 Butir 14 yang menyebutkan bahwa pendidikan anak usia dini adalah suatu upaya pembinaan yang ditujukan kepada anak sejak lahir sampai dengan usia enam tahun yang dilakukan melalui pemberian rangsangan pendidikan untuk membantu pertumbuhan dan perkembangan jasmani dan rohani agar anak memiliki kesiapan dalam memasuki pendidikan lebih lanjut. Berdasarkan pendapat-pendapat tersebut, maka dapat ditegaskan bahwa anak usia dini adalah anak yang berada dalam rentang usia 0-6 tahun. Anak usia dini berada pada masa keemasan yang tepat untuk pemberian rangsangan pendidikan, untuk mengoptimalkan pertumbuhan dan perkambangan anak. pemberian rangsangan pendidikan perlu memperhatikan karakteristik anak, sehingga potensi anak dapat berkembang dengan optimal.

Tujuan umum pendidikan anak usia dini adalah untuk membantu mengambangkan seluruh potensi dan kemampuan fisik, intelektual, emosional, moral dan keagamaan secara optimal dalam lingkungan yang kondusif, demokratis dan kompetitif (UU No. 20 tahun 2003 tentang Sistem Pendidikan Nasional). Sementara itu Solehudin (2008) mengemukakan bahwa fungsi pendidikan anak usia dini adalah: (1) Pengembangan potensi; (2) Penanaman dasar-dasar qaidah dan keimanan; (3) Pembentukan dan pembiasaan perilaku yang diharapkan; (4) Pengembangan pengetahuan dan keterampilan dasar dan (5) Pengembangan motivasi dan sikap positif terhadap belajar. Sedangkan Partini (2010: 8-12) oleh Trisniwati (2014) mengungkapkan bahwa karakteristik anak usia dini akan mengalami perubahan dan perkembangan sesuai usianya. Secara biologis perkembangan anak-anak dapat dibagi menjadi 6 fase perkembangan, mulai dari usia 0 sampai 6 bulan, 7 sampai 12 bulan, 13 sampai 24 bulan, 3 sampai 4 bulan, 5 tahun, dan sampai 8 tahun. Karakteristik anak usia dini, khususnya usia anak-anak TK adalah mulai dari usia 4 sampai 6 tahun.

\section{Media Pembelajaran Anak Usia Dini}

Secara bahasa media berasal dari kata "Medius" yang berarti tengah perantara atau pengantar. Dalam bahasa Arab mengandung arti perantara atau pengantar pesan. Menurut Hernik dan kawan-kawan bahwa istilah medium 
sebagai perantara yang mengantar informasi antara sumber dan penerima. Hamijaja dan Latuheru (1993) memberi batasan media sebagai sarana bentuk perantara yang digunakan oleh manusia untuk menyampaikan atau menyebarkan ide, gagasan, pendapat, sehingga dapat sampai kepada penerima yang dituju. Adapun nilai- nilai, manfaat media belajar dan jenis karakteristik media pembelajaran adalah sebagai berikut:

a. Nilai-nilai media belajar

Sudjana dan Rivan (2007:7). Mengemukakan bahwa penggunaan media

pengajaran dalam proses mengandung nilai-nilai sebagai berikut:

1) Meletakkan dasar yang nyata sehingga tidak terjadi Verbalisme;

2) Meningkatkan minat menulis permulaan pada siswa;

3) Penggunaan media dapat meningkatkan hasil belajar;

4) Memberikan pengalaman nyata pada siswa;

5) Menumbuhkan pola fikir yang berkembang;

6) Membantu efisiensi pengalaman yang lebih sempurna.

b. Manfaat Media Belajar:

1) Media belajar dapat meningkatkan proses belajar siswa dan dapat meningkatkan hasil belajar siswa;

2) Metode pembelajaran akan lebih perpariasi;

3) Mengatasi keterbatasan ruang dan waktu;

4) Memberikan pengalaman belajar secara langsung;

c. Jenis dan karakteristik media pembelajaran:

1) Media Audio adalah jenis media yang digunakan dalam proses pembelajaran dengan hanya melibatkan indera pendengaran peserta didik.

2) Media Cetak adalah media pembelajaran yang di sajikan dalam bentuk tercetak media jenis ini termasuk pada kelompok media paling tua dan banyak di gunakan dalam proses pembelajaran contohnya: majalah,buku paket, dan lain-lain.

3) Media Visual: adalah jenis media yang di gunakan hanya mengandalkan indera penglihatan peserta didik semata-mata,

4) Media Audio-visual

Sesuai dengan namanya media ini merupakan kombinasi dari media audio dan media visual atau biasa di sebut media pandang dengar.

\section{Pembelajaran Menulis Permulaan}

Menulis adalah suatu keterampilan yang dapat dipelajari setelah aspek kemampuan lainnya dikuasai. Salah satunya adalah aspek koordinasi motorik halus dan adanya kemampuan persepsi visual.

Keterampilan motorik halus adalah penggunaan bagian tubuh atau otot-otot kecil seperti tangan. Dalam hal perkembangan menggenggam (prehension), dicatat bahwa anak usia 12-15 bulan sudah bisa memegang benda dengan ibu jari dan telunjuk, sehingga mereka sudah dapat menyusun dua balok ke atas (dalam Mother And Baby, 2008).

Ada beberapa bentuk latihan menulis permulaan yang dapat kita lakukan, antara lain berikut ini :

1) Latihan memegang pensil dan duduk dengan sikap dan posisi yang benar. 
Tangan kanan berfungsi untuk menulis, tangan kiri untuk menekan buku tulis agar tidak mudah tergeser.

2) Latihan gerakan tangan. Mula-mula melatih gerakan tangan di udara dengan telunjuk sendiri, atau dengan bantuan alat seperti pensil. Kemudian dilanjutkan dengan latihan dalam buku latihan.

3) Latihan mengeblat, yakni menirukan atau menebalkan suatu tulisan dengan menindas tulisan yang sudah ada. Latihan menghubung-hubungkan tanda titik yang membentuk tulisan. Latihan dapat dilakukan pada buku-buku yang secara khusus menyajikan latihan semacam ini.

4) Latihan menatap bentuk tulisan latihan ini dimaksudkan untuk melatih kordinasi antara mata, ingatan, dan jemari anak ketika menulis, sehingga anak dapat mengingat bentuk kata/huruf dalam benaknya, dan memindahkannya ke jemari tangannya.

5) Latihan menyalin, baik dari buku pelajaran maupun dari tulisan guru pada papan tulis.

6) Latihan menulis halus/indah. Latihan dapat dilakukan dengan menggunakan buku bergaris untuk latihan menulis atau buku otak.

\section{Penggunaan Media Kartu Huruf untuk Pembelajaran}

Kartu huruf merupakan abjad-abjad yang dituliskan pada potonganpotongan suatu media, baik karton, kertas maupun papan tulis (tripleks). Potongan-potongan huruf tersebut dapat dipindahkan sesuai keinginan pembuat suku kata, kata maupun kalimat. Azhar Arsyad (2005: 119) dalam Trisniwati (2014) mengungkapkan bahwa kartu huruf adalah kartu abjad yang berisi gambar, huruf, tanda simbol, yang meningkatkan atau menuntun anak yang berhubungan dengan simbol-simbol tersebut. Namun demikian kata huruf yang dimaksud disini adalah kartu huruf yang dibuat sendiri dengan bentuk awan terbuat dari kertas putih dan dilaminating. Penggunaan kartu huruf ini sangat menarik perhatian siswa dan sangat mudah dilakukan dalam pembelajaran menulis dan membaca permulaan. Selain itu, kartu huruf juga melatih kreatifitas siswa. Pendapat Ratnawati (dalam Suyanto, 2012:108) mengungkapkan bahwa, melalui media kartu huruf yang di implementasikan melalui permainan, dapat merangsang untuk lebih cepat mengenal simbol-simbol huruf, membuat minat anak semakin kuat untuk bereksplorasi dalam menemukan kosakata baru, dengan cara merangkaikan simbol- simbol huruf tersebut.

1. Menulis permulaan melalui penggunaan kartu huruf membantu anak dalam proses pembelajaran.

2. Dengan situasi yang menggembirakan serta dengan suasana yang akrab menciptakan situasi yang menggambarkan perkambangaan anak usia TK.

3. Media kartu huruf digunakan untuk membantu perkembangan daya ingat anak pada tahap menulis permulaan.

Maimunah Hasan (2009: 66) dalam Trisniwati (2014) menyatakkan bahwa beberapa manfaat yang dapat diambil dari permainan kartu huruf yaitu:

1. Dapat membaca dengan mudah. Permainan kartu huruf dapat membantu anak untuk mengenal huruf dengan mudah, sehingga membantu anak-anak 
dalam kemampuan membacanya.

2. Mengembangkan daya ingat otak kanan. Permainan kartu huruf dapat mengembangkan kemampuan otak kanan karena dapat melatih kecerdasan emosi, kreatif, dan intuitif.

3. Memperbanyak perbendaharaan kata. Permainan kartu huruf terdapat gambar dan tulisan dari makna gambar yang tertera pada kartu, sehingga dapat memperbanyak perbendaharaan kata yang dimiliki anak-anak.

Disamping itu, fungsi kartu huruf dijelaskan oleh John D. Latuheru (Hendry Kurniawan, 2002: 24) mengungkapkan fungsi permainan kartu huruf adalah sebagai berikut:

1. Kondisi atau situasi saat permainan sangat penting bagi anak didik karena anak-anak bersikap lebih positif terhadap permainan kartu itu.

2. Permainan dapat mengajarkan fakta dan konsep secara tepat guna

3. , dengan cara pembelajaran konversional pada objek yang sama.

4. Pada umumnya permainan kartu dapat meningkatkan motivasi belajar anak didik, permainan dapat juga mendorong siswa untuk saling membantu satu sama lain.

5. Bantuan yang paling baik dari media permainan adalah domain efektif (yang menyangkut perasaan atau budi pekerti) yaitu memberi bantuan motivasi untuk belajar serta bantuannya dalam masalah yang menyangkut perubahan sikap.

6. Guru maupun siswa dapat menggunakan permainan kartu mana yang mengandung nilai yang paling tinggi dan bermakna untuk mencapai tujuan pembelajaran.

\section{Metode Penelitian}

Metode penelitian yang dilakukankan dalam penelitian ini adalah penelitian tindakan kelas (Classroom Action Research) yang merupakan suatu penelitian untuk memecahkan suatu masalah dalam sebuah tindakan untuk memperbaiki proses pembelajaran. Alasan dalam memilih metode PTK ini yaitu karena penelitian ini bertujuan untuk memecahkan suatu permasalahan pembelajaran di kelas yang dilaksanakan dalam 3 siklus. Setiap siklus terdiri dari 3 tahap. Dalam penelitian ini peneliti menggunakan desain penelitian menurut Elliot. Instrument yang digunakan dalam penelitian ini adalah instrumen observasi, wawancara dan dokumentasi.

Dalam tahap ini meliputi berbagai kegiatan untuk persiapan penelitian, diantaranya:

1. Membuat rencana pembelajaran yaitu Rencana Kegiatan Harian (RKH) sesuai tema yang telah ditetapkan.

2. Menyiapkan media yang akan digunakan.

3. Mengembangkan bahan ajar berdasarkan tema yang mendukung pada kegiatan pembelajaran.

4. Menyusun tehnik pengamatan pada setiap tindakan penelitian berupa format observasi, catatan lapangan, wawancara, alat evaluasi, dan kamera foto.

5. Menggunakan lembar penelitian yang telah dipersiapkan.

6. Sosialisasi instrumen penilaian pada teman sejawat.

Tahap tindakan, merupakan implemantasi dari semua rencana yang telah 
disusun sebelumnya. Peneliti melakukan tindakan yang harus di lakukaan sebagai upaya untuk melakukan perbaikan, peningkatan, atau perubahan yang di inginkan sesuai sekenario pembelajaran yang termuat dalam rencana kegiatan harian yang telah dipersiapkan.

Observasi pada penelitian ini merupakan kegiatan yang dilakukan untuk pengumpulan data melalui pengamatan berlangsung pada saat proses pembelajaran berlangsung. Hal yang diamati adalah

Pelaksanaan pembelajaran yang telah di susun melalui Rencana Kegiatan Harian (RKH), setiap gerak gerik anak, kinerja anak dan seluruh aspek perkembangannya, serta paparan terkait perubahab-perubahan yang terjadi pada variabel terikat, dalam hal ini kemanpuan motorik halus.

Refleksi pada penelitian ini bagaimana mengkaji secara menyeluruh tindakan yang telah dilakukan berdasarkan data yang terkumpul sebagai evaluasi untuk menyempurnakan tindakan berikutnya.

Penelitian ini dilaksanakan pada Anak TK Intan Komara Kelompok B tahun pelajaran 2014/2015. Jumlah siswa 15 orang yang terdiri atas 6 orang lakilaki dan 9 orang perempuan.

\section{B. PEMBAHASAN}

Tindakan yang dilakukan dalam penelitian ini adalah sebanyak tiga siklus, yang masing-masing siklus terdiri atas tiga tindakan. Setiap tindakan menekankan penggunaan kartu huruf. Adapun perbedaan dari tiap siklusnya yaitu tema dan sub tema pada materi dalam proses kegiatan. Pada penelitian ini, peneliti berperan sebagai guru dalam proses kegiatan pada PTK.

Adapun langkah-langkah pada penelitian ini melalui metode kartu huruf dengan: Guru menyiapkan kartu yang dibuat sendiri dengan bentuk yang beragam, ada yang berbentuk awan dan bulat. Setiap kartu diberikan huruf a-z. pembelajaran dimulai pukul 07.45 guru sudah bersiap di kelas menyambut kedatangan anak, guru menyapa anak dan mengucapkan salam pada guru. Anak menyimpan tas pada kelas kelompok B yang sudah dipersiapkan. Setelah pukul 08.00 guru mengajak anak berbaris di depan kelas.

Hal yang dapat dijadikan sebagai indikator keberhasilan penelitian tindakan kelas adalah apabila data yang diperoleh telah menunjukkan adanya perolehan hasil evaluasi maksimal selama penelitian dengan kriteria indikator kuantitatifnya menunjukkan daya serap individual minimal $65 \%$, daya serap klasikal $70 \%$ dan ketuntasan klasikal $80 \%$, maka dapat dianggap tuntas belajar. (Depdiknas,2001).

Hasil Penelitian Pengembangan kemampuan menulis anak diukur dalam beberapa indicator, pada siklus 1 proses menulis anak masih banyak yang mendapat bintang dua (**) atau masih dalam kategori kurang berkembang. Pada siklus ini terdapat temuan bahwa anak kesulitan dalam Mengenal huruf dengan warna merah, kuning, hijau dengan latihan Huruf $p$ dan e diwarnai dengan warna merah, huruf 1 dan a diwarnai dengan warna kuning, huruf $\mathrm{n}, \mathrm{g}$ dan i diwarnai dengan warna hijau. Setelah dilaksanakan tindakan siklus I ternyata kemampuan anak dalam menulis permulaan dibandingkan pada saat tindakan, meskipun dalam hal ini sudah menunjukkan peningkatan tetapi belum mencapai standar yang 
diharapkan. Hal ini disebabkan karena sebagian besar anak belum mampu berlatih menulis melalui kartu huruf yang disiapkan oleh guru, Sebagian besar anak masih belum mampu untuk mmenulis huruf yang terdapat pada kartu huruf. Selain itu anak masih membutuhkan waktu yang cukup lama untuk menulis permulaan, dan sebagian besar anak masih belum mampu untuk menebalkan huruf, sehingga masih ada anak yang belum mau memegang pensil ketika guru memberikan tugas. Tindakan penelitian ini dilakukan dengan tiga tindakan siklus I dengan harapan anak-anak terbiasa dengan tugas-tugas yang diberikan oleh guru disertai dengan media pembelajaran yang digunakan oleh guru seperti kartu huruf. Proses pembelajaran yang sangat kurang menarik anak selama ini dan tidak menggunakan media pembelajaran, serta banyak aktivitas yang didominasi oleh guru atau pembelajaran yang berpusat pada guru. Hal inilah yang mendorong peneliti untuk melakukan perbaikan pembelajaran dengan menggunakan kartu huruf yang diharapkan mampu meningkatkan kemampuan menulis anak dalam mengenal huruf.

Dalam kemampuan menulis anak, dapat dilihat bahwa dari 15 anak yang menjadi subyek penelitian, pengamatan menulis permulaan melalui media kartu huruf terdapat $78 \%$ anak yang memperoleh bintang tiga pada tindakan 1,87\% pada tindakan 2 dan $91 \%$ pada tindakan 3. Berdasarkan persentase yang diperoleh pada pengamatan siklus II tidak semua tindakan anak mencapai indikator persentase ketuntasan dalam kategori belum berkembang sangat baik dalam 3 pengamatan yaitu Mengenal huruf dengan baik, Melengkapi huruf dengan benar, Kerapihan membuat huruf. Oleh sebab itu, akan dilakukan lagi proses perbaikan pada pelaksanaan tindakan selanjutnya.

Sementara itu, pada siklus III kemampuan menulis yang diperoleh dari 15 anak yang menjadi subyek penelitian, pengamatan menulis permulaan melalui media kartu huruf terdapat $81 \%$ anak yang memperoleh bintang tiga pada tindakan 1, 91\% pada tindakan 2 dan $98 \%$ pada tindakan 3. Berdasarkan persentase yang diperoleh pada pengamatan siklus III sudah mencapai indikator persentase ketuntasan dalam kategori berkembang sangat baik. Oleh sebab itu, tidak akan dilakukan proses perbaikan pada pelaksanaan tindakan selanjutnya. Hal ini disebabkan karena guru pada tindakan siklus III telah memperbaiki proses pembelajaran dan mengelola kegiatan pembelajaran dengan baik.

\section{Pembahasan}

Pada siklus 1, kemampuan menulis anak masih rendah. Sebagian besar anak belum mampu merespon penjelasan dan pertanyaan yang diberikan oleh guru. Anak masih belum mampu menulis dengan baik dan benar, karena anak masih belum terbiasa menulis dengan langkah-langkah kegiatan yang dilakuakannya. Oleh karena itu, pada siklus 1 ini, guru sangat berperan penting untuk membimbing dan membina anak supaya dapat menulis dengan perlahan dan dapat menulis dengan baik dan benar. Tetapi sebelum guru memberikan pengarahan untuk menulis kepada anak, guru memberikan permainan melalui kartu, yaitu dengan menerbangkan kartu dan anak disuruh memilih kartu kemudian menyebutkan huruf apa yang berada pada kartu tersebut. Dengan diberikannya permainan seperti ini, anak menjadi antusias dan semangat dalam menulis. Ditambah lagi ketika istirahat anak diberikan permainan bebas sesuka 
hati mereka. Dengan otomatisketika jam pelajaran tiba anakpun sudah semangat lagi kembali belajar.

Kemudian pada siklus II, kemampuan menulis anak mengalami peningkatan. Tetapi masih dalam ketuntasan kategori belum berkembang sangat baik dalam 3 pengamatan yaitu Mengenal huruf dengan baik, Melengkapi huruf dengan benar, Kerapihan membuat huruf. Oleh sebab itu, dilakukan wawancara dengan beberapa anak, diperoleh jawaban bahwa anak menyukai metode pembelajaran kartu huruf. Hal itu dikarenakan pada umumnya anak-anak menyukai huruf yang dibuat unik dengan tulisan yang berwarna-warni.

Sementara itu, pada siklus III kemampuan menulis anak meningkat secara sigmifikan. Hal ini terlihat dari hasilanakyang memperoleh persentase $91 \%$. Dan juga dapat terlihat dari reaksi respon anak dengan baik.

Secara umum dapat dikatakan bahwa proses kegiatan menulis anak dari siklus I sampai siklus III dikatakan meningkat dan mencapai target yang diharapkan. Hal ini dikarenakan peneliti menggunakan metode Kartu huruf pada proses pembelajaran anak. Karena sebagaimana diungkapkan oleh Maimunah Hasan (2009: 66) dalam Trisniwati (2014) menyatakkan bahwa beberapa manfaat yang dapat diambil dari permainan kartu huruf yaitu: Dapat membaca dengan mudah, mengembangkan daya ingat otak kanan dan memperbanyak perbendaharaan kata.

\section{KESIMPULAN}

Berdasarkan hasil penelitian dan pembahasan, maka dapat disimpulkan hal- hal sebagai berikut:

1. Proses pembelajaran menulis permulaan belajar anak dalam kegiatan menulis permulaan dengan menggunakan media kartu huruf di TK Intan Komara pembelajarannya meningkat. Hal ini dapat di buktikan dengan kegiatan proses belajar anak yang semakin hari semakin lebih baik.

2. Kemampuan menulis permulaan siswa telah menggunakan media kartu huruf mengalami peningkatan pada setiap siklusnya. Siswa dapat menulis kata dan menulis kalimat sederhana yang berhubungan dengan huruf $b, d, n, m, f, y, w$, dan z. kemudian untuk penilaian tiap-tiap aspek dalam menulis juga mengalami peningkatan dengan mencapai target bintang tiga, pengamatan menulis permulaan melalui media kartu huruf pada siklus I terdapat $71 \%$ pada tindakan $1,78 \%$ pada tindakan 2, dan $87 \%$ pada tindakan 3.pada siklus II $78 \%$ anak yang memperoleh bintang tiga pada tindakan $1,87 \%$ pada tindakan 2 dan $91 \%$ pada tindakan. Dan pada siklus III terdapat $81 \%$ anak yang memperoleh bintang tiga pada tindakan 1, 91\% pada tindakan 2 dan 98 $\%$ pada tindakan 3.

\section{DAFTAR PUSTAKA}

Abidin, Yunus (2011). Penelitian Pendidikan dalam gamintan Pendidikan dasar dan PAUD. Rizky Press: Bandung

Depdiknas. 2000. Permainan Membaca dan Menulis di Taman Kanak- kanak. Jakarta : Depdiknas.

Endah, Tri B (2014). Penggunaan Permainan Kartu kata bergambar untuk 
meningkatkan kemampuan membaca permulaan pada anak kelompok $B$ RA Muslimat NU. Yogyakarta

Kemendikbud (2013). Petunjuk Teknis Penylenggaraan Taman Kanak-kanak. Tim Direktorat pembinaan Pendidikan Anak Usia Dini

Kurniasih, Ening (2013). Penggunaan media kartu huruf untuk meningkatkan kemampuan membaca permulaan. Universitas terbuka : Garut

Langi, Tahir, dan idris. Peningkatan kemampuan membaca dan menulis dengan menggunakan kartu huruf di kelas 1 SDN 2 Wombo. Program Guru Fakultas Keguruan dan ilmu pendidikan: Universitas Tadulako

Samini (2010). Peningkatan keterampilan menulis permulaan dengan menggunakan kartu huruf pada siswa kelas 1 SDN Keslatan 5 Kecamatan banjarsari Surakarta. Fakultas Keguruan dan Ilmu Pendidikan Universitas Muhammadiyah: Surakarta

Sujiono, Bambang. 2005. Metode Pengembangan Fisik. Jakarta: Universitas Terbuka

Trisniwati (2014). Peningkatan Kemampuan Mengenal Huruf Melalui Metode Permainan Kartu Huruf Pada Kelompok B1 Tk Aba Ketanggungan Wirobrajan Yogyakarta. Universitas Negeri Yogyakarta

Zaman, Hernawan, dan Eliyawati (2005). Media dan sumber belajar TK. Komendiknas 